\title{
PENGADOPSIAN UNCAC MENGENAI PENGEMBALIAN ASET HASIL \\ KORUPSI YANG DIBAWA ATAU DISIMPAN KE LUAR NEGERI DALAM PENEGAKAN HUKUM INDONESIA
}

\author{
Fikry latukau, Widati Wulandari
}

Fikry18001@mail.unpad.ac.id

Program Studi Magister Hukum Universitas Padjadjaran Bandung

\begin{abstract}
Corruption is a universal problem involving the whole country and a complicated problem that is difficult to eradicate, this has nothing to do with the problem of corruption not only related to economic issues alone, but also related to political issues, defense and law enforcement. one of them is in upholding the criminal act of corruption which results from corruption is taken abroad, requesting assets resulting from corruption is very important considering the results of the results of corruption are the main objective in eradicating these criminal acts of corruption. This writing uses normative legal research methods, because the authors do not conduct field studies. UNCAC, in assistance involving deterrent influence, because biapu convicts or corruptors save or hoard the wealth of the results of surveillance abroad, will be tracked and sent to the State, thereby helping to make this report for law enforcement and lawmakers to be able to formulate legal policies in corruption cases.
\end{abstract}

Key words: Corruption, Asset recovery, enforcement of Indonesian law.

\begin{abstract}
Abstrak
Korupsi merupakan permasalahan universal yang dihadapi oleh seluruh negara dan masalah pelik yang sulit untuk diberantas, hal ini tidak lain karena
\end{abstract}


masalah korupsi bukan hanya berkaitan dengan permasalahan ekonomi semata, melainkan juga terkait dengan permasalahan politik, kekuasaan dan penegakkan hukum. salah satunya dalam penegakkan hukum tindak pidana korupsi yang hasil dari korupsinya dibawa ke luar negeri, pengembalian aset hasil korupsi ini sangat penting mengingat mengembalikan hasil dari korupsi adalah tujuan utama dalam meberantas tindak pidana korupsi tersebut. Penulisan ini menggunakan metode penelitian hukum normatif, karena penulis tidak melakukan studi lapangan. Tujuannya agar pembaca dapat mengetahui pentingnya UNCAC, dalam upaya penanganan maupun menimbulkan efek jera, karena biapu terpidana atau koruptor menyimpan atau menimbun kekayaan hasil korupsi diluar negeri, akan dilacak dan dikembailkan kepada Negara, dengan begitu maka manfaat tulisan ini untuk para penegak hukum dan para legislator untuk dapat merumuskan kebijakan hukum pidana dalam perkara tindak pidana korupsi.

\section{kata kunci : Korupsi; Pengembalian asset; penegakan hukum Indonesia}

\begin{abstract}
A. Pendahuluan
Kehidupan manusia yang semakin maju seiring perkembangan teknologi mengakibatkan banyak kejahatan-kejahatan pidana dengan modus baru bahkan dilakukan dengan skala internasional/transnasional yang merupakan tindak pidana internasional.Tindak pidana korupsi tidak lagi merupakan masalah nasional, melainkan sudah menjadi
\end{abstract}

fenomena

transnasional. ${ }^{1}$

Berdasarkan hal tersebut kerjasama internasional menjadi hal yang esensial dalam mencegah dan memberantas tindak pidana korupsi,

\footnotetext{
1 Melani, "Problematik Prinsip Double Criminality Dalam Hubungannya dengan Kerjasama Pencegahan dan Pemberantasan Kejahatan transnasional", Jurnal Ilmu Hukum Litigasi, Vol. 6 No. 2, Juni 2005, hal. 169; Mar-sono, "Pemberantasan Korupsi di Indonesia: Dari Pers-pektif Penegakan Hukum", Manajemen Pembangunan,No. 58/II/ Tahun XVI, 2007, hal. 58-61; Sugiyanto E Ku-suma, "The relationship Between Money Laundering and banking",Jurnal Keuangan dan Perbankan, Vol. 11 No. 1
} 
khususnya dalam upaya koruptor menyembunyikan hasil korupsinya melalui pencucian uang dengan menggunakan transfer-transfer internasional yang efektif. $^{2}$ Tidak sedikit aset publik yang berhasil dikorup telah dilarikan dan disimpan pada sentra finansial di negaranegara maju yang terlindungi oleh sistem hukum yang berlaku di negara tersebut dan oleh jasa para profesional yang disewa oleh koruptor. ${ }^{3}$ Pelacakan aset adalah hal yang kompleks karena merupakan hal yang tidak mudah untuk melacak apalagi untuk memperoleh kembali aset tersebut sehingga negara-negara berkembang di mana grand corruption umumnya terjadi sangat merasakan kenyataan tersebut sebagai kesulitan dalam upaya memperoleh kembali aset yang dicuri dan disembunyikan pada sentra sentra finansial dunia.

2 Nurmalawaty, "Faktor Penyebab terjadinya Tindak Pidana Pencucian uang (Money Laundering)dan Upaya Pencegahannya", Jurnal Equality,Vol. 11 No. 1, Februari 2006, hal. 16,17

3 Fanny Frikasari, "Kejahatan Bisnis Dalam Perspektif Hu-kum Pidana Indonesia", Jurnal Ilmu Hukum Litigasi, Vol. 6 No. 2, Juni 2005, hal. 202
Indonesia

nampaknya merupakan surga bagi koruptor, Tindak Pidana Korupsi dinyatakan bahwa di Indonesia sudah meluas dalam masyarakat. Perkembangannya terus meningkat dari tahun ke tahun, baik dari jumlah kasus yang terjadi dan jumlah kerugian keuangan negara maupun dari segi kualitas tindak pidana yang dilakukan semakin sistematis serta lingkupnya yang memasuki seluruh aspek kehidupan masyarakat. Meningkatnya tindak pidana korupsi yang tidak terkendali akan membawa bencana tidak saja terhadap kehidupan perekonomian naşional tetapi juga pada kehidupan berbangsa dan bernegara pada umumnya. Ada juga dari segi historis, budaya dan penegakan hukum itu sendiri. Dari segi historisnya korupsi dimulai sejak pendudukan Belanda dimana perusahaannya bernama VOC telah malakukan praktek korupsi, ditambah lagi zaman orde baru korupsi ada di semua sistem pemerintahaan. Budaya korupsi menjadi kebiasaan akibat kurangnya pendidkan tentang korupsi tersebut, ditambah lagi semakin terkikisnya 
budaya rasa malu akibat melakukan korupsi. Penegakan hukum terhadap pelaku tindak pidana kurang maksimal contohnya rencana hukuman mati terhadap koruptor yang belum terlaksana.

Pemerintah terkesan lambat dalam proses pemberantasan dan penegakan terhadap koruptor apa lagi terhadap elit di pemerintahaan. Korupsi sering melibatkan struktur pemerintah sehingga para penegak hukum tersebut terlibat dalam praktek korupsi. Apalagi yang mempunyai hubungan dengan kekuasaan dan konlomerat, saat diproses, terkesan formalitis, sekedar memenuhi tuntutan rakyat, sekalipun ada yang lolos ke pengadilan dan dijatuhi pidana, merekahanyalah koruptor kelas teri, sedangkan koruptor kelas kakap banyak divonis bebas, atau bahkan sudah melarikan diri terlebih dahulu ke luar negeri. ${ }^{4}$

${ }^{4}$ A Djoko Sumaryanto, "Rancangan Model Penyidikan Tindak Pidana Korupsi di Indonesia", Supremasi Hukum,Januari 2005, hal. 12; lihat juga Otto Cornelis Kaligis, "Korupsi sebagai Tindakan Kriminal yang Harus Di-berantas: Karakter dan Prektek Hukum di Indonesia", Jurnal Equality, Vol. 11 No. 2, Agustus 2006, hal. 152
Pemerintah sebagai aparatur negara yang memiliki kekuasaan eksekutif yang diatur dalam Undangundang Dasar 1945 Bab III Pasal 4 sampai dengan Pasal 15 memiliki kewenangan yang sangat luas dalam menentukan kebijakan yang berkaitan dengan pemulihan atau perbaikan keadaan negara pada kondisi yang sebelumnya. Upaya pemerintah Indonesia dalam mengatasi korupsi tersebut terlihat dengan lahirnya beberapa peraturan perundang-undangan diantaranya Undang-undang Nomor 31 Tahun 1999 ten-tang Pemberantasan Tindak Pidana Korupsi, Undang-Undang Nomor 20 Tahun 2001 tentang Perubahan atas Undang-Undang No. 31 Tahun 1999 tentang Pemberantasan Tindak Pidana Korupsi, Undang-Undang No. 25 Tahun 2003 tentang Tindak Pidana Pencucian Uang serta peraturan perundangan lainnya yang secara khusus dibentuk untuk mengatasi tindak pidana ini.

Dunia internasional menganggap perlu adanya suatu international regulation yang secara tegas dan spesifik mengatur 
mengenai tindak pidana yang lazim disebut white collar crime atau kejahatan kerah putih. Tekad dunia internasional untuk memberantas korupsi diwujudkan dengan lahirnya United Nations ConventionAgaints Corruption, 2003 (UNCAC 2003) yang diterima oleh Sidang Majelis Umum PBB (SMU PBB) pada tanggal 31 Oktober 2003 melalui Resolusi SMU PBB A/58/4. SMU PBB juga menyatakan bahwa Konvensi terbuka untuk ditandatangani oleh negara-negara PBB dalam suatu acara khusus di Merida, Mexico pada tanggal 9-13 Desember 2003. Hingga kini telah terdapat 140 negara penandatangan dan telah ada 107 yang menundukkan diri sebagai negara pihak. Konvensi telah mulai berlaku sejak 14 Desember 2005 dan merupakan The First Legally Binding Glo-bal Anticorruption Agreement (Persetujuan Pertama yang Mengikat Secara Hukum Mengenai Anti Korupsi).

$$
\text { Korupsi merupakan }
$$
permasalahan universal yang dihadapi oleh seluruh negara dan masalah pelik yang sulit untuk diberantas, hal ini tidak lain karena masalah korupsi bukan hanya berkaitan dengan permasalahan ekonomi semata, melainkan juga terkait dengan permasalahan politik, kekuasaan dan penegakkan hukum. ${ }^{5}$ Konvensi ini (UNCAC) memberikan enforcement (paksaan) bagi contracting states (negara pihak) untuk melaksanakan kewajibankewajiban yang ter-cantum di dalamnya termasuk sanksi bagi negara pihak yang tidak melaksanakan kewajiban. Salah satu materi penting Konvensi adalah tentang asset recovery (pengembalian aset) dari aset yang dilarikan ke luar yurisdiksi negara asal melalui kerjasama internasional. Hal ini merupakan suatu paradigma baru dalam pemberantasan korupsi secara global. Secara khusus, pengembalian aset dimuat dalam Chapter V Asset Recovery UNCAC Pasal 51 UNCAC mengatur bahwa: "Thereturn of assets pursuant to this chapter is a fundamental principle of this Convention, and

\footnotetext{
${ }^{5}$ Marsono, "Pemberantasan Korupsi di Indonesia dari Perspektif Penegakkan Hukum", Manajemen Pembangun-an,No. 58/II/TahunXVI, 2007, hal. 57-62.
} 
Parties shall afford one another the widest measure of cooperation and assistance in this regard". Pasal tersebut secara tegas menyatakan bahwa pengembalian asset merupakan prinsip mendasar dimana negara anggota konvensi diharapkan dapat saling bekerja sama membantu dalam pengembalian aset yang dimaksud dalam konvensi ini.

Upaya negara-negara Pihak Konvensi termasuk Indonesia dalam mengembalikan aset hasil korupsi yang berada di luar yurisdiksi mereka tentunya akan dipermudah dengan adanya ketentuan yang secara tegas menyatakan bahwa upaya pengembalian aset adalah suatu prinsip mendasar yang harus dihormati dan dilaksanakan oleh negara-negara Pihak tersebut. Pentingnya pengembalian aset juga terlihat dari upaya Bank Dunia dan PBB dalam peluncuran sebuah inisiatif baru untuk mewujudkan efektifitas UNCAC di markas besar PBB di New York pada 18 September 2007 dalam pemberantasan korupsi terutama baik negara-negara berkembang maupun di negara maju yang disebut Stolen
Asset Recovery Initiative (StAR). Prakarasa Pengembalian Aset Hasil Curian ini dibentuk untuk membantu negara berkembang yang kesulitan untuk mengambil asethasil korupsi yang disembunyikan di negaranegara maju.Permasalahan yang dihadapi saat ini adalah sistem penegakan hukum di Indonesia terutama peraturan perundangundangan baik yang berkaitan dengan hukum materiil maupun hukum acaranya belum dapat memaksimalkan pengembalian aset tersebut.

Oleh karena hal tersebut persoalan-persoalan yang dikemukakan diatas sekaligus mengisyaratkan keterkaitan dan kompleksitas permasalahan hukum yang muncul dari kekosongan hukum mengenai pengaturan tentang pengembalian aset hasil korupsi yang dibawa keluar negeri. Adapun masalah yang akan dibahas dalam penulisan ini adalah Bagaimana Urgensi penerapan UNCAC tentang pengembalian aset hasil korupsi yang dibawah atau disimpan ke luar negeri dalam penegakan hukum di indonesia? 
Tujuannya agar pembaca dapat mengetahui pentingnya UNCAC, dalam upaya penanganan maupun menimbulkan efek jera, karena biapu terpidana atau koruptor menyimpan atau menimbun kekayaan hasil korupsi diluar negeri, akan dilacak dan dikembailkan kepada Negara, dengan begitu maka manfaat tulisan ini untuk para penegak hukum dan para legislator untuk dapat merumuskan kebijakan hukum pidana dalam perkara tindak pidana korupsi.

\section{B. Hasil Dan Pembahasan}

Penelusuran aset pada umumnya berkaitan dengan pengembalian kembali aset yang dimiliki oleh suatu negara/organisasi atau suatu entitas yang diambil oleh pihak lain dengan cara melawan hukum seperti perbuatan tindak pidana korupsi dan atau tindak pidana pencucian uang. Aset yang diambil secara melawan hukum tersebut oleh pelaku disembunyikan sedemikian rupa misalnya dibelikan ke aset tetap seperti bangunan, tanah, kendaraan, atau disimpan dalam bentuk sertifikat deposito, diinvestasikan dalam surat berharga saham, obligasi atau cara lain yang dilakukan pelaku untuk dapat mengaburkan asal usul aset tersebut. Tujuan penelusuran aset adalah untuk mengetahui keberadaan dan jenis aset yang disembunyikan dari hasil tindak pidana, yang akan digunakan untuk penggantian kerugian negara.

Penelusuran Aset (Asset Tracing), Menurut BPKP dalam Modul Audit Forensik (2007) yang dimaksud dengan penelusuran asetadalah merupakan suatu teknik yang digunakan oleh seorang investigator/auditor forensik dengan mengumpulkan dan mengevaluasi bukti-bukti transaksi keuangan dan non keuangan yang berkaitan dengan asethasil perbuatan tindak pidana korupsi dan atau tindak pidana pencucian uang yang disembunyikan oleh pelaku untuk dapat diidentifikasikan, dihitung jumlahnya, dan selanjutnya agar dapat dilakukan pemblokiran/pembekuan dan penyitaan untuk pemulihan kerugian akibat perbuatan pelaku tindak pidana korupsi dan atau tindak 
pidana pencucian uang tersebut. ${ }^{6}$ Pengembalian Aset Lintas Batas,meliputi proses/kegiatan baik melalui pengadilan pidana maupun perdata untuk mencari, membekukan dan mengembalikan asset yang didapat dari kegiatan yang melanggar hukum kepada negara. Menurut Hukum Nasional Asset Recovery dapat dilakukan secara pidana, perdata, dan administratif. Maksud Pengembalian Aset yaitu meliputi kegiatan penelusuran, pengamanan, pemeliharaan, perampasan dan pengembalian asset yang juga mencakup penghapusan dan pemusnahan asset. Untuk mewujdukan tata kelola pemerintahan yang baik (good governace), pemulihan asset harus dilaksanakan secara efektif, efesien, transparan dan akuntabel.

\footnotetext{
${ }^{6}$ Muhammad fuatwidyaiswara, penelusuran aset (asset tracing) dan pemulihan kerugian negara (loss recovery), Pusat Pendidikan dan Pelatihan Pengawasan BPKP, dimuat https://www.google.com/url?sa=t\&rct=j\&q= \&esrc=s\&source=web\&cd=1\&cad=rja\&uact $=8 \&$ ved $=2$ ahUKEwii8Pegsq7iAhUD6nMB HZKLD3EQFjAAegQIBRAC\&url=http $\% 3$ A\%2F\%2Fpusdiklatwas.bpkp.go.id\%2Fasse t\%2Ffiles\%2Fpost\%2F20140225_142244\% 2FPenelusuranAset.docx\&usg=AOvVaw20 Sc6LAoywitT2ynE1GGbo
}

Penegakan hukum pidana, pada hakekatnya tidak hanya bertujuan menghukum pelaku tindak pidana (kejahatan/pelanggaran) agar menjadi jera atau tidak mengulagi perbuatannya, tetapi bertujuan memulihkan kerugian yang diderita oleh korban secara finansial akibat dari perbuatan pelaku tersebut, semua ini sesuai asas dominus litis merupakan tugas tanggung jawab penegak hukum.Pemulihan asset merupakan proses penanganan aset hasilkejahatan yang dilakukan secara terintegrasidi setiap tahap penegakan hukum, sehingganilai aset tersebut dapat dipertahankan dandikembalikan seutuhnya kepada korbankejahatan, termasuk kepada negara.Pemulihan aset juga meliputi segala tindakan yang bersifat prefentif untukmenjaga agar nilai aset tersebut tidakberkurang. ${ }^{7}$ Pengembalian aset-aset negara yangdicuri (stolen asset recovery)sangat penting bagi

${ }^{7}$ Romli Atmasasmita, Asset Recovery dan MutualAssistance In Criminal Matters,Pelatihan HukumPidana dan Kriminologi Asas-asas Hukum Pidanadan Kriminologi serta perkembangannya DewasaIni, Mahupiki dan FH Universitas Gadjah Mada,Yogyakarta, 23-27 Februari 2014, hal 6. 
pembangunan

negara-

negaraberkembang

karena

pengembalian aset-aset yang dicuri

tidak semata-mata merestorasi asetaset negara tetapi juga bertujuan untukmenegakan supremasi hukum dimana tidaksatu orang pun kebal terhadap hukum. ${ }^{8}$

Prinsip asset recovery diatur secara eksplisit dalam Konvensi Anti Korupsi. Ketentuan Pasal 51 (article 51) Konvensi Anti Korupsi "The return of assets pursuant to this chapter is a fundamental principle of this Convention, and States Parties shall afford one another the widest measure of cooperation and assistance in this regard". (Pengembalian aset menurut bab ini merupakan prinsip dasar Konvensi ini, dan Negara Pihak wajib saling memberikan kerjasama dan bantuan seluas mungkin untuk itu). secara teknis memungkinkan tuntutan, baik secara perdata (melalui gugatan)

\footnotetext{
${ }^{8}$ Widyopramono, "Peran Kejaksaan Terhadap AsetRevocery Dalam Perkara Tindak Pidana Korupsi",Pelatihan Hukum Pidana dan Kriminologi "Asas-asas Hukum Pidana dan Kriminologi sertaPerkembangannya Dewasa ini”, KerjasamaMAHUPIKI dan Universitas Gadjah Mada,Yogyakarta, 23-27 Februari 2014, hal 4.
}

maupun secara pidanapengembalian aset negara yang telah diperoleh oleh seseorang melalui perbuatankorupsi.Konvensi Anti Korupsi ini punmemungkinkan dilakukannya tindakan-tindakan perampasan atas kekayaan tanpapemidanaan dalam hal pelaku tidak dapatdituntut dengan alasan meninggal dunia, lari (kabur) atau tidak hadir dalam kasus-kasuslain yang sama.

Sampai saat ini dalam usaha untuk mengejak asset yang ada di luar negeri masih memerlukan kerjasama antarinstansi (agent to agent) \& Mutual Legal Asistance, memerlukan kerjasama berbagai instansi secara terintegrasi, seperti PPATK, Kepolisian, Kejaksaan, KPK dan Kementerian Hukum dan HAM, namun perlu juga dibentuk suatu peraturan khusus mengenai pengembalian aset hasil korupsi yang dibawa ke luar negeri sehinga dapat menghasilkan kepastian hukum serta mempermudah penegakan hukum dalam penanganan pengembalian aset tersebut. 
Langkah produktif yang harus ditempuh untuk dilaksanakan guna mengatasi kejahatan transnasional adalah dengan meratifikasi berbagai ketentuan hukum pidana internasional.Lahirnya UNCAC tersebut menjadi angin segar bagi negara-negara berkembang yang mengalami permasalahan korupsi, Konvensi PBB tentang Pemberantasan Korupsi (United Nation Convention Against Corruptionatau UNCAC) mengatur tentang aset recovery pada $\mathrm{Bab} \mathrm{V}$, pengembalian aset ini merupakan perinsip yang mendasardalam UNCAC 2003.

Tindak pidana korupsi pada umumnya merupakan kejahatan yang memiliki karakteristik tersendiri. Perlu dikemukakan bahwa pada dasarnya, terdapat banyak karakteristik dari tindak pidana korupsi. Beberapa tindak pidana korupsi dimaksud adalah sebagai berikut : ${ }^{9}$

${ }^{9}$ Kristian, Yopi Gunawan, Tindak Pidana Korupsi kajian terhadap harmonisasi anatara hukum nasional dan The United Nations Convention Againt Convention (UNCAC), Pt Radika Aditama, Bandung, 2015, hal 48 . a) Tindak pidana korupsi sebagai kejahatan kerah putih (white collar crime)

b) Tindak pidana korupsi sebagai kejahatan terorganisir (organized crime);

c) Tindak pidana korupsi sebagai kejahatan biasa (extra ordinary crime) dan yang baru (new dimention of crime).

d) Tindak pidana korupsi sebagai kejahatan lintas batas negara yang terorganisir (trans national organized crime)

e) Tindak pidana korupsi sebagai tindak pidana yang berdampak luar biasa (extra ordinary crime)

f) Tindak pidana korupsi sebagai kejahatan dengan dimensi-dimensi baru (new demention crime)

Dari sejumlah karakteristik tindak pidana korupsi diatas, perlu dibahas terkait beberapa tindak pidana yang ada kaitannya dengan Transnasional dan berpeluang untuk membawa 
hasil korupsinya ke luar negeri tindak pidana korupsi tersebut diantarannya yaitu : 1 . Tindak pidana korupsi sebagai kejahatan lintas batas negara yang terorganisasi (transnational organized crime), 2. Tindak pidana korupsi sebagai kejahatan dengan dimensi-dimensi yang baru (New Dimention of Crime).

1. Tindak Pidana Korupsi sebagai Kejahatan Lintas Batas Negara yang Terorganisasi (Transnational Organized Crime)

Tindak pidana korupsi dapat dikategorikan sebagai kejahatan lintastas negara yang terorganisasi (transnational organized crime) karenamemenuhi kriteria kejahatan lintas batas negara yang terorganisasi (transnational organized crime) sebagaimana diatur secara tegas dalam The United Nations Convention Against Transnational Organized (UNCATOC) atau konvensi Perserikatan BangsaBangsa (PBB) menentang tindak pidana transnasional yang terorganisasi. Pasal 1 The United Nations Convention Against
Transnational Organized Crime (UNCATOC) dengan tegas menyatakan bahwa the purpose of this convention is to promote cooperation to prevent and combat transnational organized crime more effectively (tujuan dari konvensi ini adalah untuk memajukan kerja sama untuk mencegah dan memberantas tindak pidana transnasional terorganisasi secara lebih efektif).

Dilihat dari tujuan The United Nations Convention Against Transnational Organized Crime Tahun 2000 tersebut di atas, terbukti adanya peningkatan kejahatan atau tindak pidana dan keprihatinan masyarakat internasional mengenai kejahatan yang berkembang dewasa ini, yang tidak saja merupakan masalah suatu negara, tetapi juga merupakan masalah global yang salah satunya adalah tindak pidana korupsi.

Pada dasarnya, tindak pidana korupsi dapat dikategorikan sebagai kejahatan transnasional yang bersifat terorganisir. Dikatakan demikian karena tindak pidana korupsi selalu melibatkan orang-orang yang 
membentuk sebuah jaringan atau suatu sistem yang berkaitan dan tidak dapat dilepaskan satu dengan yang lainnya. Di samping itu, orang-orang yang terlibat dalam tindak pidana korupsi mempunyai fungsi peranannya masing-masing sehingga tidak mudah untuk diungkap,ditindak, dan diberantas oleh para aparatur penegak hukum.

Tindak pidana korupsi dapat dikatakan sebagai salah satu bentuk dari kejahatan transnasional yang terorganisasi

(transnational organized crime) dapat pula dilihat dari kriteria kejahatan transnasional terorganisasi yang terdapat dalam Pasal 3 ayat (2) The United Nations Convention Against Transnational Organized Crime (UNCATOC) tahun 2000 yang menyatakan sebagai berikut : a. It is committed in more than one state (Hal ini dilakukan di lebih dari satu Negara); b. It is commited in one state but substansial part of its preparation planning, direction or control takes place in another state (Hal ini dilakukan di satu negara tetapi bagian substansialnya, perencanaan, arah, persiapan, atau kontrol terjadi di negara lain) c. It is committed in one state but involves an organized criminal group that engaged in criminal activities in more than one state (Hal ini dilakukan di satu negara tetapi melibalkan suatu kelompok penjahat terorganisasi yang terlibat dalam kegiatan kriminal di lebih darisatu negara) d. It is committed in one state but has substantial effects in another state (Hal ini dilakukan di satu negara tetapi memiliki efek atau dampak yang substansial di negara lain) Tindak Pidana Korupsi sebagai Tindak Pidana yang Berdampak Luar Biasa (Extra Ordinary Crime)

2. Tindak Pidana Korupsi sebagai Kejahatan dengan Dimensi-Dimensi yang Baru (New Dimention of Crime)

Karakteristik tindak pidana korupsi berikutnya adalah tindak pidana dengan dimensi-dimensi yang baru. Penulis beranggapan demikian karena modus operandi tindak pidana korupsi senantiasa berkembang seiring dengan perkembangan zaman dan perkembangan masyarakat Singkatnya, modus operandi tindak 
pidana korupsi di tahun 1990-an tentunya akan berbeda dengan modus operandi tindak pidana korupsi yang dilakukan pada tahun 2000-an, dan akan berbeda pula dengan modus operandi tindak pidana korupsi yang dilakukan di tahun 2015 ini.

Dengan demikian, tindak pidana korupsi merupakan tindak pidana dengan dimensi-dimensi kejahatan yang akan senantiasa berkembang baik modus operandi maupun alat yang digunakannya seiring dengan perkembangan zaman, perkembangan masyarakat, dan perkembangan ilmu pengetahuan. Untuk menanggulangi hal ini, tentu hukum juga tidak dapat statis melainkan harus mengikuti perkembangan zaman, perkembangan masyarakat dan perkembangan dunia internasional khususnya dalam rangka penanggulangan (mencegah dan memberantas) tindak pidana korupsi. Penulis beranggapan bahwa tindak pidana korupsi dengan dimensidimensi baru ini tidak menutup kemungkinan muncul juga penemua atau cara yang di rencanakan oleh koruptor sehingga memperkecil kemungkinan mereka mengembalikan aset yang telah di korupsi kepada negara.

Tujuan UNCAC dimuat dalam Bab I Pasal 1 Pernyataan Tujuan adalah; pertama, meningkatkan dan memperkuat tindakan-tindakan untuk mencegah dan memberantas korupsi secara lebih efisien dan efektif; kedua, Meningkatkan, memudahkan dan mendukung kerja sama internasional dan bantuan tehnik dalam upaya pencegahan dan pemberantasan korupsi, termasuk pengembalian aset; dan meningkatkan integritas, akuntabilitas dan pengelolaan masalah serta kekayaan publik dengan baik dan benar.Tujuan tersebut menjadi akar dibentuknya reformasi dalam menanggulangi permasalahan korupsi transnasional.Berpegang teguh pada prinsip saling menghormati kepada masing-masing negara pihak konvensi kemudian dicapai kesepakatan untuk menggunakan UNCAC sebagai dasar hukum untuk menindak para koruptor.

Komponen yang terdapat dalam pasal UNCAC telah membawa 
progres ke arah yang lebih maju mengenai kebutuhan akan bantuan yang bersifat teknis untuk membantu agenda anti korupsi yang diakui oleh semua negara, baik negara berkembang maupun negara maju. Kebutuhan tersebut diakomodir dan dipenuhi sesuai dengan isi yang terkandung dalam UNCAC. Negara tetap berperan utama dalam pemberantasan tindak pidana korupsi karena negaralah yang memiliki state sovereignty (kedaulatan negara) sehingga berkuasa atas hal-hal yang terjadi atasnya. Segala bentuk tindakan yang diambil oleh negara menjadi tanggung jawabnya secara penuh baik mulai dari tahap perencanaan hingga hasil akhir.

Negara peserta dan peratifikasi konvensi telah memahami sepenuhnya dan menyetujui penggunaan sarana hukum untuk pengembalian aset korupsi sebagai bagian dari tanggung jawab kolektif semua negara, bukan saja negara yang harta kekayaannya telah dikorupsi. Kerjasama antar negara ini menjadi penting mengingat korupsi bukan lagi kejahatan lokal atau nasional. Ia telah menjadi kejahatan luar biasa (extraordinary crime) yang bersifat transnasional karena bisnis sudah bersifat transnasional, melewati lintas batas negara. Terdapat tiga upaya dalam usaha pengembalian aset luar negeri melalui UNCAC. Pertama, dengan menuntut para koruptor melalui civil allegation(perdata). Hal itu dimaksudkan untuk membekukan aset milik negara agar bisa dibekukan di negara tempat aset tersebut disimpan. Selain itu, demi menghambat agar aset tersebut tidak lari, pemerintah pun akan melakukan full disclosure(pengungkapan penuh)agar tidak mampu tersentuh lagi oleh ulah koruptor. Kedua, pemerintah melalui UNCAC bisa melakukan perampasan paksa terhadap aset fisik yang dimiliki koruptor di luar negeri. Ketiga, meng-gunakan kekuatan konvensi tersebut di dalam negara-negara yang dicurigai sebagai tempat bersembunyinya koruptor. Ada beberapa Instrumen UNCAC 2003 yang diatur dalam ketentuan hukum di Indonesia yang dijelaskan pada pembahasan berikutnya. 
Urgensi pengaturan Asset Recovery Dalam Undang-undang Tindak Pidana Korupsi atau Undangundang Khusus. Beberapa kasus korupsi yang bersifat transnasional dan berkaitan langsung dengan asset recovery diantaranya adalah Hasil wawancara Bank Dunia dengan PBB pada tanggal 24 September 2007 menyatakan bahwa Soeharto telah ditetapkan oleh PBB dan Bank Dunia sebagai orang terkorup di dunia pada tahun 2006. Diikuti dengan 9 orang terkorup di dunia lainnya yaitu Ferdinand Marcos dari Filipina yang berada pada peringkat kedua hingga Joseph Estradadi peringkat kesepuluh yang juga ber-asal dari Filipina.Montesinos, pejabat tangan kanan Presiden Alberto Fujimoriyang berkuasa di Peru sejak 28 Juli 1990 hingga 17 November 2000 yang diketahui memiliki sejumlah rekening di Bank-bank asing di dunia; Ferdinand Marcossebagai Presiden Filipina periode November 1965 hingga Februari 1986 diketahui melakukan korupsi besar-besaran dan menyembunyikan aset hasil curiannya di bank-bank asing di dunia.Berdasarkan uraian tersebut, penulis tertarik untuk membahas mengenai bagaimana urgensi ketentuan UNCAC 2003 dalam peraturan nasional agar dapat mengoptimalisasi pengembalian asset hasil korupsi melalui Perjanjian Internasional.

Penyitaan bukan kita yang melakukan penyitaan untuk bedah yurisdiksi. Undang-undang KPK Pasal 12 huruf h menjelaskan KPK bisa meminta bantuan penegak hukum (setempat) untuk melakukan penyitaan atas hasil tindak pidana atau barang bukti yang terdapat di luar negeri, Peraturan mahkamah agung nomor 01 tahun 2013.Regulasi terkait perampasan aset koruptor di luar negeri sebenarnya sudah ada, yakni Undang-Undang Republik Indonesia Nomor 1 Tahun 2006 tentang Bantuan Timbal Balik Dalam Masalah Pidana. Pada Pasal 9 disebutkan bahwa (1) Menteri dapat mengajukan permintaan Bantuan kepada negara asing secara langsung atau melalui saluran diplomatik. Disebutkan juga bahwa permintaan bantuan sebagaimana 
dimaksud pada ayat (1) diajukan oleh Menteri berdasarkan permohonan dari Kapolri atau Jaksa Agung. Sedangkan (3) Dalam hal tindak pidana korupsi, permohonan bantuan kepada Menteri selain Kapolri dan Jaksa Agung juga dapat diajukan oleh Ketua Komisi Pemberantasan Tindak Pidana Korupsi, Peraturan Mahkamah Agung Nomor 01 Tahun 2013 tentang Tata Cara Penyelesaian Permohonan Penanganan Harta Kekayaan Dalam Tindak Pidana Pencucian Uang menjelaskan tata cara pengembalian aset.

Untuk menyelesaiakan
permasalahan yuridis terkait
perampasan aset, maka diperlukanlah
instrumen perundang-undangan yang
khusus untuk mengatur mengenai
perampasan aset, baik dari segi
materiel maupun formil. Dalam
konsep Rancangan Undang-Undang
(RUU) tentang perampasan aset yang
masuk dalam program legislasi
nasional (prolegnas) maka ada
beberapa hal yang masih perlu
dilakukan penyempurnaan-
penyempurnaan yang lebih baik dan
komprehensif. Tujuan dari RUU

Perampasan ini adalah mencakup 3 (tiga) aspek penting, yaitu:

a. mengatasi kendala-kendala yang timbul dalam upaya penarikan atau pengembalian aset melalui mekanisme pidana (in personam), sehingga walaupun tersangka/terdakwanya meninggal dunia, melarikan diri, sakit permanen, atau tidak diketahui keberadaannya, penyitaan dan perampasan aset hasil tindak pidana tetap dapat dilakukan secara fair karena melalui pemeriksaan sidang pengadilan.

b. mendorong terwujudnya pengelolaan aset tindak pidana yang profesional, transparan dan akuntabel dengan pembentukan lembaga pengelola aset.

c. memudahkan Pemerintah Indonesia dalam meminta bantuan kerjasama pengembalian aset (aset recovery) dari pemerintahan negara lain yang pada 
umumnya mensyaratkan adanya putusan pengadilan baik pidana maupun perdata.

Perampasan aset tindak pidana yang direncanakan dalam RUU tentang Perampasan Aset ini adalah bagian yang tidak terpisahkan dari kampanye dunia melawan korupsi. Melalui United Nations Convention Againts Corruption (UNCAC) telah diusahakan adanya kerjasama antar negara melawan korupsi ini, antara lain dengan meningkatkan kemampuan negara-negara berkembang "merampas kembali" aset yang telah dicuri oleh para koruptor dan disembunyikan di luar. Selain itu, dalam proses perancangan perlu untuk diperhatikan mengenai anatomi ketentuan pasal yang ada dalam RUU Perampasan Aset, RUU Perampasan Aset haruslah mengatur terkait beberapa hal di bawah ini, yaitu:

1. Prinsip-prinsip yang utama;

2. Definisi Aset dan Delik menurut NCB Asset Forfeiture;

3. Upaya investigasi dan preservasi aset;
4. Konsep-konsep prosedur dan pembuktian;

5. Para pihak dalam proses peradilan dan syarat pemberitahuan;

6. Putusan Pengadilan;

7. Pertimbangan organisasi dan (dalam) pengelolaan kembali aset;

8. Kerjasama Internasional dan “perampasan kembali” aset.

Dalam perkembangannya, untuk dapat merampas kembali (recover) aset yang disembunyikan para koruptor Indonesia di luar negeri, maka paling tidak diperlukan dua syarat utama, yaitu: ${ }^{10}$

1. Indonesia juga harus mempunyai sistem peradilan yang jelas dan tegas melawan korupsi (dalam hal ini Undang-undang Korupsi, KPK dan Pengadilan Tipikor);

2. Indonesia harus juga mempunyai undang-undang

${ }^{10} \mathrm{http}: / /$ kanalhukum.id/kanalis/tinja uan-konsep-pengembalian-aset-assetrecovery-hasil-tindak-pidana-dalam-ruuperampasan-aset/46. Diakses pada kamis 16 Agustus 2019, pukul 04:20 WIB. 
yang jelas dalam merampas kembali aset yang dicuri oleh para koruptor (baik aset yang disembunyikan di dalam negeri, maupun di luar negeri)

Terutama kalau Indonesia ingin merampas (recover) aset koruptor Indonesia yang berada di luar negeri, maka kedua syarat di atas akan sangat menentukan. Indonesia tidak akan dapat begitu saja meminta/merampas aset koruptor Indonesia di luar negeri, tetapi harus melalui jalur hukum negara di mana aset tersebut ditempatkan. Indonesia adalah yang meminta (requesting state), atau "Negara Korban", dan negara lain tersebut adalah yang kita minta bantuannya (requested state), "negara tempat aset". Terdapat 2 (dua) jenis perampasan yang dipergunakan secara internasional untuk memperoleh kembali hasil korupsi, yaitu menurut hukum pidana dan menurut hukum perdata. Perampasan menurut hukum perdata (civil forfeiture) sedangkan perampasan menurut hukum pidana seperti yang kita kenal dalam KUHP (criminal forfeiture). ${ }^{11}$

Peraturan mengenai pengembalian aset hasil korupsi yang dibawa ke luar negeri belom terlalu sistematis dan memadai sehingga peenangannya juga belum terlalu maksimal.

Menurut Sajipto Raharjoi, ada dua fungsi yang dapat dimainkan oleh hukum yaitu sebagai social controlmengandung arti bahwa betugas untuk menjaga masyarakat tetap berada dalam pola-pola tingkah laku yang telah diterima olehnya. Dalam rangka prespektif hukumsebagai social cintrol fungsi utama sisterm hukm bersifat integrative. Maksudanya hukum untuk mengatur dan memelihara regulitas social. Tanpa hukum, manusian bias menjadi homo homini lupus (manusia yang satu menjadi serigala bagi manusia lainnya). Tiada masyarakat yang bias hidup lama tanpa control social dari hukum didalamnya.

$$
{ }^{11} \text { lbid }
$$


Beberapa instrument hukum yang perlu dibentuk sebagai bentuk ratifikasi terhadap UNCAC 2003 yang belum diatur di Indonesia di antaranya adalah sebagai berikut. Pertama,pengembalian aset melalui jalur non conviction base(in rem system)dalam sistem hukum acara perdata nasional dengan prinsip bahwa yang dinyatakan jahat adalah benda yang diduga berasal dari tindak pidana korupsi sehingga benda tersebut dapat langsung disita oleh negara sampai ada pemilik yang sah dapat membuktikan bahwa benda tersebut bukan hasil dari kejahatan atau digunakan untuk melakukansuatu kejahatan. Pihak yang mengaku,apabila dapat membuktikan,maka akan dikembalikankepadanya tetapi jika tidak maka harta tersebut menjadi milik Negara dan siapa yang mengaku tersebut dapat diperiksa karena dapat dinyatakan sebagai orang yang mengaku tetapi tidak dapat membuktikan sehingga dapat dijerat pasal-pasal dalam tindak pidana umum seperti penipuan ataupun pemalsuan surat-surat jika terbukti.
Kedua, membut instrument hukum dalam Kitab Undang-Undang Hukum Acara Pidana khususnya dalam hal pembuktian terbalik artinya setiap pejabat Negara ataupun pihak yang diutungkan dari perbuatan tindak pidana korupsi harus membuktikan asal muasal hartanya dan membuktikan kepada pengadilan darimana harta tersebut berasal, hal ini juga berlaku bagi pejabat atau pegawai negeri yang mendapatkan pertambahan harta kekayaan yang signifikan yang diduga mendapatkan kekayan secara tidak sah/halal (illicit enrichment) (Pasal 20 UNCAC 2003). Pada saat ini pembuktian terbalik hanya dikhususkan untuk tindak pidana gratifikasiyang nilainya hanya diatas Rp. 10.000.000,-(sepuluh juta rupiah) seharusnya bukan hanya tindak pidana gratifikasi tetapi untuk seluruh tindak pidana korupsi dapat dimintakan proses pembuktian terbalik (Pasal 12 B ayat (1) huruf (a) Undang-Undang No. 20 Tahun 2001 jo UU No. 31 Tahun 1999 tentang Pemberantasan Tindak Pidana Korupsi). 
Ketiga,membuat/membentuk suatu lembaga yang khusus dalam mengelola dan mengadministrasikan aset-aset yang dikorupsi dengan membentuk suatu lembaga baru ini maka seluruh aset-aset hasil tindak pidana (bukan hanya tindak pidana korupsi) baik yang ada di dalam negeri maupun di luar negeri ditampung dan dikelola dalam badan pengelola aset tersebut hal ini sangat penting mengigat banyak-nya instansi penegak hukum yang merasa berwenang untuk menyimpan dan mengelola aset-aset hasil tindak pidana atau yang digunakan melakukan tindak pidana sehingga agar memunculkan masalah bagaimana jika hilang, berkurang ataupun bonus, bunga dari aset tersebut kepada siapa diberikan.

\section{Penutup}

Sampai saat ini dalam usaha untuk mengejak asset yang ada di luar negeri masih memerlukan kerjasama antar instansi (agent to agent) \&Mutual Legal Asistance, memerlukan kerjasama berbagai instansi secara terintegrasi, seperti PPATK, Kepolisian, Kejaksaan,
KPK dan Kementerian Hukum dan HAM.Pengembalian aset-aset negara yang dicuri (stolen asset recovery) sangat penting bagi pembangunan negara, Ketentuan Pasal 51(article 51) UNCAC (Pengembalian aset menurut bab ini merupakan prinsip dasar Konvensi ini, dan Negara Pihak wajib saling memberikan kerjasama dan bantuan seluas mungkin untuk itu). secara teknis memungkinkan tuntutan, baik secara perdata (melalui gugatan) maupun secara pidana pengembalian aset negara yang telah diperoleh oleh seseorang melalui perbuatan korupsi.

Suatu negara yang bersedia meratifikasi suatu perjanjian internasional, berarti negara tersebut bersedia untuk mengikatkan diri pada perjanjian internasional dan tunduk pada isi atau hak dan kewajiban yang terkandung dalam perjanjian internasional. Disamping itu, perlu disadari bahwa dengan pengikatan diri tersebut, berarti negara yang bersangkutan telah menerima perjanjian internasional itu sebagai bagian dari hukum nasionalnya. Dengan demikian, pengikatan diri pada perjanjian internasional 
mengandung dua segi, yaitu segi ekstern yang berarti bahwa negara yang bersangkutan menerima perjanjian internasional tersebut sebagai hukum internasional yang melahirkan hak-hak dan kewajiban dari segi intern, yaitu perjanjian internasional tersebut diterima atau menjelma menjadi hukum nasionalnyayang juga melahirkan hak-hak dan kewajiban bagi negara itu sendiri maupun negaranya.

Indonesia termasuk telah lama juga meratifikasi Konvensi (United Nations Convention Against Corruption), akan tetapi masih banyak ketentuan-ketentuan Hukum Nasional di bidang korupsi yang belum diselaraskan dengan konvensi tersebut, umpamanya mengenai kriminalisasi terhadap pejabat publik asing dan swasta, demikian juga dalam hal asset recoverybelum ada dasar hukum yang kuat yang dapat digunakan khusus dalam pengembalian asset hasil korupsi yang dibawa atau disimpan ke luar negeri. Yang ada saat ini baru perjajian bilateral terhadap beberapa negara berupa MLA (Mutual Legal Asistance) yang bersifat umum.
Sehingga pengembalian asset hasil korupsi belum bisa maksimal.

Oleh karena itu perlu membuat aturan-aturan untuk menselaraskan Konvensi PBB Anti Korupsi Tahun 2003 dengan peraturan pemberantasan korupsi dalam hukum nasional Indonesia dalam Undang-undang Nomor 31 Tahun 1999 jo Undang-undang Nomor 20 tahun 2001 maupun dalam KUHP yang akan datang. Dalam rangka mempercepat pengembalian asset (asset recovery) perlu dibentuk suatu lembaga di bawah struktur Komisi Pemberantasan Korupsi (KPK) yang bertugas untuk mengurus hal-hal yang berkaitan dengan pengembalian aset negara yang diduga milik pelaku tindak pidana korupsi yang berada di luar negeri, di mana terdiri dari unsur Interdep atau lintas instansi antara lain: Kepolisian, Kejaksaan, Kemenlu, Kemenkumham, Bank Indonesia, dan pakar Hukum.Sulitnya pemerintah dan lembaga berwenang untuk mengusut dan mengembalikan aset hasil kejahatan korupsi, narkotika, terorisme dan pencucian uang, maka 
mendesak diperlukannya Undang- aset sampai dengan pengelolaan aset. Undang yang mengatur perampasan

\section{Daftar Pustaka}

\section{Daftar Pustaka}

Erwin Ubwarin, Yonna B. Salamor. (2017). Mekanisme Pengembalian Kerugian Negara oleh Terpidana yang Meninggal Dunia Pasca Putusan Mahkamah Konstitusi Nomor 25/PUU-XIV/2016. Jurnal Muara Ilmu Sosial, Humaniora, dan Seni , 51-57.

Frikasari, F. (2005). Kejahatan Bisnis Dalam Perpektif Hukum Pidana Indonesia. Jurnal Ilmu Hukum Litigasi .

Jaya, N. S. (2010). Bahan Kuliah Sistem Peradilan Pidana (Criminal Justice Sytem). Semarang: Universitas Diponegoro (UNDIP).

Kaligis, O. C. (2006). Korupsi Sebagai Tindak Pidana Kriminal Yang Harus Diberantas; Karakter Dan Praktek Hukum di Indonesia. JURNAL Equality .

Soedarto. (1977). Hukum dan Hukum Pidana. Bandung.

Sumaryanto, A. D. (2005). Rancangan Model Penyidikan Tindak Pidana Korupsi di Indonesia. Supermasi Hukum, 12.

Susanto, I. (2015). Kejahatan Korporasi. Semarang: BP UNDIP. Yopi Gunawan, K. (2015). Tindak Pidana Korupsi Kajian Terdahapan Harmonisasi Antara Hukum Nasional dan The United Nations Convention Againt Covention (UNCAC). Bandung: PT Radika Adiatam.

http://kanalhukum.id/kanalis/tinjauan-konsep-pengembalian-aset-asset-recoveryhasil-tindak-pidana-dalam-ruu-perampasan-aset/46. Diakses pada kamis 16 Mei 2019, pukul 04:20 WIB.

https://ugm.ac.id/id/berita/410masih.sulitnya.mengembalikan.aset.koruptor.di.luar .negeri. Diakses pada kamis 16 agustus 2019, Pukul 05:15 WIB. 